\title{
SIKAP RAMAH LINGKUNGAN SISWA SMP NEGERI 8 SEMARANG MELALUI PELATIHAN HIDROPONIK
}

\author{
Intan Rizky Amalia'), Fajrina Asabela Putri' ${ }^{2)}$, Siti Musapana ${ }^{3)}$, \\ Dika Wahyuningrum ${ }^{4}$, Cucianingsih $^{5}$ \\ 1,2,3,4,5)Pendidikan Biologi, FPMIPATI, Universitas PGRI Semarang \\ 1intanamaliara@gmail.com, ${ }^{2}$ fasabela14@gmail.com, ${ }^{3}$ musapana8@gmail.com, \\ dikawahyuningrum16@gmail.com, ${ }^{5}$ ucisoedarnooo@gmail.com
}

\section{Diterima 24 Agustus 2019 disetujui 25 September 2019}

\begin{abstract}
The low preservation of the environment makes the atmosphere less cool. One solution to the problem related to environmental preservation is by planting through hydroponics. The aim is to build an environmentally friendly attitude to students of SMP N 8 Semarang and to bring up students' desire to grow crops. Planting in a hydroponic manner in addition to helping preserve the environment, can also be useful to meet food consumption, health, and improve student concentration when the environment is beautiful. The hydroponics training was conducted by the laboratory at SMP $N 8$ Semarang for 3 dayS. The purpose of this study was to determine the environmentally friendly attitude of students of SMP Negeri 8 Semarang through hydroponic training. The method used is hydroponic observation training, interviews and questionnaires for students of SMP N 8 Semarang before being given training and after training using a behavioral checklist. From the results of the study showed that there was a comparison of scores between before and after, namely the questionnaire before treatment obtained an average of 79.1 and the questionnaire after treatment obtained an average of 91.4. From these data means that students care about the environment and students' interest in hydroponics is getting better. This was stated because students had taken the training activities seriously. This article concludes that to preserve the school environment the environment friendly attitude of students of SMP N 8 Semarang is treated through hydroponic training.
\end{abstract}

Key Words : ecofriendly,training,hydroponics

\section{PENDAHULUAN}

Sekolah merupakan sarana sebagai tempat belajar. Namun tidak hanya sekedar belajar saja, melainkan perlu sarana pendukung agar tercipta suasana yang nyaman proses belajar mengajar juga akan berjalan lebih kondusif. UU No. 23 tahun 1992 tentang Perlindungan dan Pengelolaan Lingkungan Hidup bahwa "kesehatan sekolah diselenggarakan untuk meningkatkan kemampuan hidup sehat peserta didik dalam lingkungan hidup sehat, sehingga peserta didik dapat belajar tumbuh dan berkembang secara harmonis dan optimal menjadi sumber daya manusia yang berkualitas" (Depkes RI, 1992 : 5). Salah satu bentuk implementasi yang sudah dilakukan di dunia pendidikan untuk pembangunan berkelanjutan berbasis Pendidikan Lingkungan Hidup yang dilaksanakan secara terprogram di sekolah adalah program Eco School. Program Eco School merupakan program internasional yang bertujuan untuk meningkatkan literasi lingkungan pada siswa. Program Eco School dikembangkan oleh Foundation of Enviromental Education (FEE) pada 
tahun 1994, yang dikembangkan atas dasar kebutuhan untuk melibatkan kaum muda dalam mencari solusi terhadap tantangan lingkungan hidup dan pembangunan berkelanjutan di tingkat lokal. Munculnya Eco School, berangkat dari keprihatinan bersama untuk memperbaiki kualitas lingkungan dengan menggabungkan pembelajaran dan tindakan.

Lahan yang sempit pada SMP Negeri 8 Semarang membuat lingkungan sekolah minim pemanfaatan. Belum lagi jika pencahayaan kurang memadai, panas, pengap, maka siswa tidak nyaman dalam pembelajaran. Padahal pembelajaran yang baik yaitu didukung dengan lingkungan yang sejuk dan sehat untuk menciptakan suasana belajar yang kondusif. Upaya membangun sikap peduli siswa terhadap lingkungan sekitar yaitu dengan bercocok tanam. Namun bagi kebanyakan siswa beranggapan bahwa bercocok tanam identik dengan tanah, kotor, membutuhkan banyak tenaga, berpanas panas di bawah terik matahari, ribet penggunaan alatnya dan hal - hal lain yang menjadikan siswa enggan terjun dalam kegiatan bercocok tanam.

Oleh karena itu, kendala - kendala yang melatarbelakangi minimnya sikap ramah siswa terhadap lingkungan dapat diantisipasi dengan pengadaan pembinaan lingkungan sekolah melalui pelatihan. Dengan adanya hal tersebut diharapkan dapat membangun sikap ramah lingkungan siswa dalam upaya pelestarian lingkungan melalui budidaya hidroponik. Dimana hidroponik merupakan teknik menanam yang praktis dan bersih. Hal ini dapat mengubah mindset siswa akan bercocok tanam yang dianggap memerlukan lahan luas, kotor, dan lain sebagainya menjadi lebih modern bahwa bercocok tanam tidak perlu lahan yang luas dan tentunya efisien. Selain itu penggunaan alat dan bahan pada hidroponik juga bisa menggunakan barang yang tidak terpakai (daur ulang) seperti botol dan gelas minuman plastik. Botol tersebut dapat digunakan dengan menyerupai gully (pralon yang berlubang) untuk tempat netpot, dan botol netpotnya dengan diberi lubang untuk pengait flannel.

Hidroponik merupakan cara yang digunakan untuk meningkatkan produktifitas tanaman terutama di lahan sempit (Siswandi dan Sarwono, 2013).Hidroponik tidak menggunakan media tanah dalam proses penanamannya dan hanya menggunakan air yang dilarutkan dengan nutrisi AB Mix. Media tanam yang digunakan dalam hidroponik menggunakan rockwool. Selain itu, penambahan nutrisi dibutuhkan untuk budidaya tanaman sistem hidroponik, baik unsur hara esensial makro maupun mikro. Nutrisi hidroponik dengan sistem hidroponik yaitu larutan AB Mix. Larutan nutrisi sebagai sumber pasokan air dan mineral nutrisi merupakan faktor penting untuk pertumbuhan dan kualitas hasil tanaman hidroponik sehingga sehat untuk dikonsumsi karena nutrisi yang ada pada $\mathrm{AB}$ mix terpenuhi.

Tujuan penulisan artikel ini adalah mengetahui sikap ramah lingkungan siswa SMP Negeri 8 Semarang melalui pelatihan hidroponik.yang pada akhirnya diharapkan siswa dapat membangun sikapnya dengan bercocok tanam menggunakan hidroponik di sekolah supaya tercipta proses pembelajaran yang lebih baik karena adanya keselarasan dalam pembelajaran dan tindakan yang akan dilakukan. 


\section{METODE}

Program kegiatan pelatihan hidroponik dilaksanakan selama 3 hari pada tanggal 18,19, dan 24 Juli 2019 berlokasi laboratorium IPA SMP N 8 Semarang dengan 34 siswa sebagai peserta. Untuk mewujudkan tujuan yang diharapkan maka dilakukan beberapa metode dalam pelatihan. Metode yang digunakan adalah demonstrasi dan tanya jawab untuk menyampaikan materi pelatihan dan dilanjutkan dengan kegiatan praktik pembelajaran sebagai implementasi hasil pelatihan.

Tahap awal yang dilakukan adalah melakukan observasi sekaligus koordinasi dan meminta perizinan kepada kepala sekolah mengenai perencanaan program pelatihan hidroponik kepada siswa-siswi SMP 8 Semarang. Tahap yang kedua adalah pelaksanaan pelatihan hidroponik dari mulai manfaat dari hidroponik, macam-macam hidroponik dan perbedaan dari masing-masing, pengenalan alat dan bahan dalam menanam hidroponik serta fungsi dari masing-masing, cara menanam hingga perawatannya. Tahap yang ketiga adalah dilakukan di sekolahan dengan melibatkan 34 siswa sebagai responden. Pengamatan dilakukan dengan observasi pengamatan aktivitas siswa, wawancara siswa dan guru dan pengisian angket dengan menggunakan behavioral checklist. Dilakukan penyusunan jadwal pelatihan dan materi.Adapun jadwal untuk setiap sesi dapat dilihat pada Tabel 1 .

Tabel 1 menunjukkan jadwal dan materi pelatihan. Pada hari 1 diberikan beberapa penjelasan terkait dengan materi hidroponik diantaranya dasar-dasar hidroponik seperti pengertian, alat dan bahan yang digunakan, pembuatan nutrisi AB Mix, cara penanaman, serta kelebihan menggunakan sistem hidroponik. Adapun teknik hidroponik yang digunakan adalah wick system (teknik sumbu). Hal ini terlihat dari keberadaan pot yang diletakan di atas instalasi hidroponik. Teknik ini dapat dikatakan sebagai sistem yang paling dasar. Oleh karena itu teknik ini sangat membantu siswa sebagai pemula yang ingin bertanam hidroponik. Menurut Alviani (2015: 41), cara seperti teknik sumbu ini mirip seperti cara kerja kompor tradisional, dimana sumbu berfungsi sebagai penyerap larutan dalam media tersebut. Instalasi/wadah untuk pembibitan menggunakan botol atau gelas air mineral bekas, maka sisi-sisinya dilubangi menggunakan solder listrik atau alat pelubang lainnya (Alviani, 2015: 57). Membuat wadah pembibitan ini ternyata tidak hanya mencerminkan karakter peduli lingkungan mengenai penggunaan barang bekas, melainakn menumbuhkan kreativitas siswa.

Tabel 1. Jadwal dan Materi Pelatihan

\begin{tabular}{|c|c|c|}
\hline $\begin{array}{l}\text { Hari/ } \\
\text { Tanggal }\end{array}$ & Jam & Materi \\
\hline $\begin{array}{ll}\text { Kamis, } & 18 \\
\text { Juli } 2019 & \end{array}$ & $\begin{array}{l}09.00- \\
11.15 \\
\text { (3 JP) }\end{array}$ & $\begin{array}{l}\text { Pengenalan } \\
\text { Hidroponik\& } \\
\text { komponennya }\end{array}$ \\
\hline $\begin{array}{l}\text { Jumat, 19 Juli } \\
2019\end{array}$ & $\begin{array}{l}09.00- \\
11.15 \\
(3 \mathrm{JP})\end{array}$ & $\begin{array}{l}\text { Praktik } \\
\text { penyemaian\& } \\
\text { pembuatan } \\
\text { instalasi } \\
\text { hidroponik }\end{array}$ \\
\hline $\begin{array}{l}\text { Rabu, } 24 \text { Juli } \\
2019\end{array}$ & $\begin{array}{l}09.00- \\
09.15 \\
\text { (Jam } \\
\text { Istirahat) }\end{array}$ & $\begin{array}{l}\text { Pengecekan } \\
\text { perkembangan } \\
\text { tanaman }\end{array}$ \\
\hline
\end{tabular}

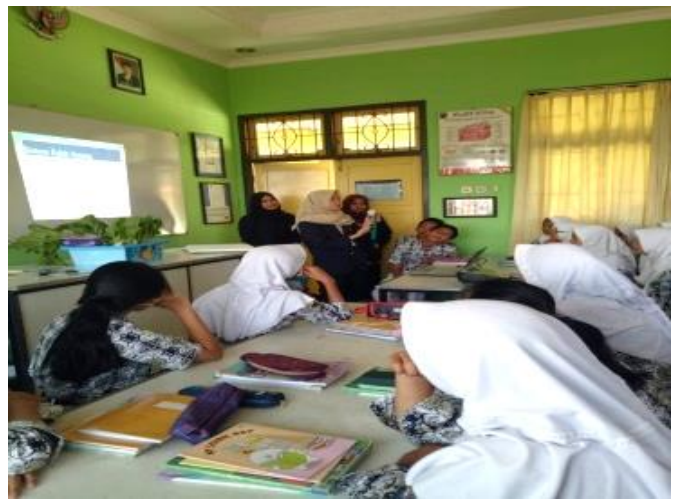

Gambar 1.Penyampaian materi dan simulasi 


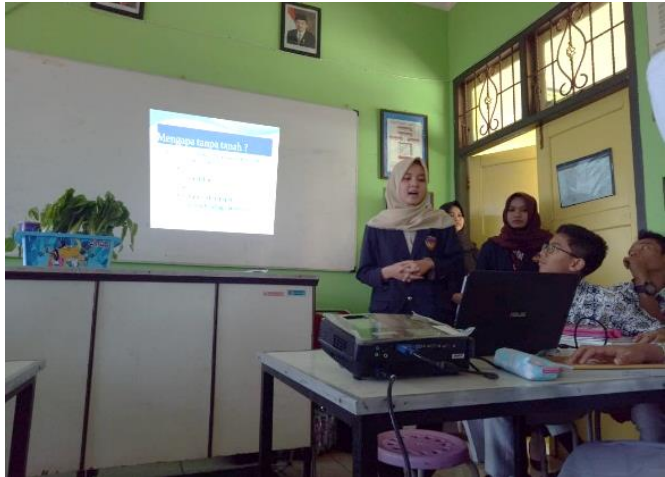

Gambar 2. Penyampaian Materi dan Simulasi

Pada hari kedua dijadwalkan untuk memberikan materi yang bersifat teknis, yaitu penyemaian. Sebelum dilakukan penyemaian pada rockwool, dilakukan terlebih dahulu perendaman benih. Pendapat Prihmantoro (1996: 37) yang menyatakan bahwa persemaian dilakukan dengan merendam benih terlebih dahulu. Perendaman tersebut difungsikan untuk mengetahui kualitas dari benih yang dipakai, apabila benih saat direndam ini terapung berarti menandakan bahwa kualitasnya kurang bagus karena benih yang mengapung memiliki berat yang lebih ringan berarti pasokan nutrisinya sedikit. Setelah itu dilakukan penyemaian dengan cara memotong rockwool menjadi ukuran 2,5x2,5 $\mathrm{cm}$ mengunakan cutter/gergaji dan pada tiap rockwool dilubangi untuk disemaikan benih sebanyak 1-2 benih per rockwool. Setelah itu diberi air secukupnya tidak samapia menggenang. Apabila diberikan air terlalu banyak, benih akan cepat membusuk karena masa awal pertumbuhan benih belum terlalu membutuhkan nutrisi yang banyak karena selnya pun masih sedikit. Pada tahapan ini, dilakukan pembagian kelompok untuk memudahkan dalam penanaman supaya efisien. Siswa dengan jumlah 34 akan dibagi menjadi 6 kelompok. Masing-masing kelompok terdiri dari 5-6 siswa. Setiap kelompok akan melakukan penyemaian dengan benih tanaman yang berbeda-beda, untuk kelompok 1-3 melakukan penyemaian bibit selada merah (lollo rossa), sedangkan untuk kelompok 4-6 melakukan penyemaian bibit sawi pagoda (tak ke cai). Hari ketiga merupakan rangkaian akhir dari keseluruhan pelatihan. Di hari terakhir ini, peserta melakukan pengecekan tanaman yang sudah disemai.

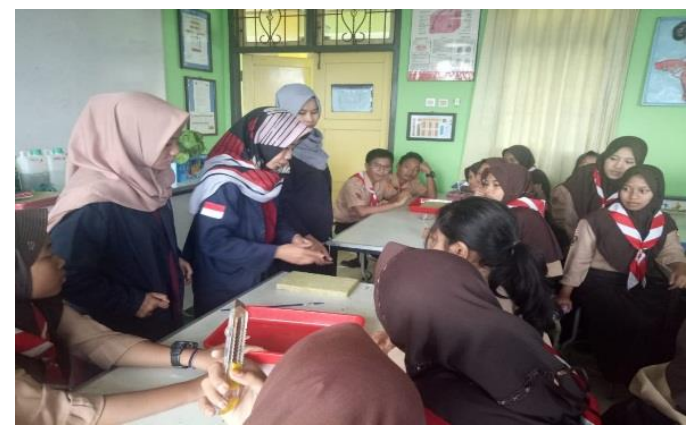

Gambar 3. Praktik Pemotongan Rockwool

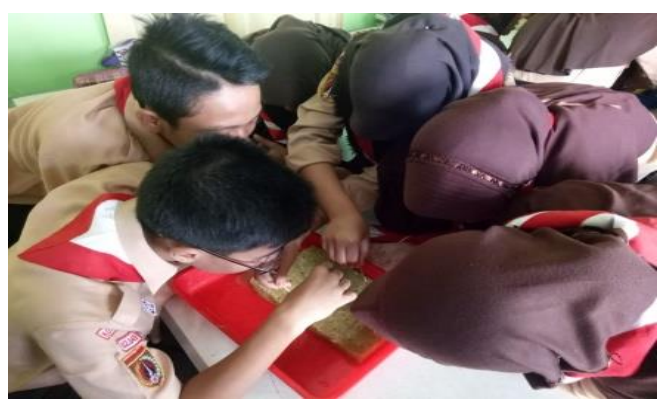

Gambar 4. Praktik Penyemaian Benih pada Rockwool

Data - data dari hasil penelitian dikumpulkan dan dianalisis dengan metode analisis data kualitatif bersifat deskriptif.Pada pengisian angket siswa disajikan 6 aspek penilaian diantaranya Pemanfaatan Media pada Hidroponik, Proses Penanaman Hidroponik, Pemahaman/ Penguasaan Materi Hidroponik, Kepedulian Siswa terhadap Lingkungan, Minat Siswa pada Pengembangan Teknologi Hidroponik, dan Pelestarian Lingkungan. Dari keenam aspek penilaian berisi $6 \mathrm{~s} / \mathrm{d} 7$ indikator sebagai penilaian siswa selama mengikuti pelatihan hidroponik. Metode yang digunakan untuk mengetahui data terebut yaitu menggunakan behavioral checklist 
dimana disajikan pernyataan dengan didukung 4 pilihan jawaban diantaranya SS (Sangat Setuju), S (Setuju), R (Ragu), dan TS (Tidak Setuju). Dari keempat pilihan jawaban tersebut memiliki poin yang berbeda-beda yaitu $S S=5 ; S=4 ; R=3$; $\mathrm{TS}=2$. Dari nilai tersebut berarti apabila siswa memilih sangat setuju, perhitungan checklist pada setiap data akan dikalikan dengan 5 untuk total skornya. Hal ini juga berlaku pada pilihan jawaban yang lainnya dengan mengikuti skor yang telah ditentukan. Setelah perhitungan skor masing - masing jawaban, kemudian menggunakan rumus sebagai berikut: (Widokoyo,2014)

$$
\text { Skor }=\frac{\text { Jumlah Skor Siswa }}{\text { Skor Maksimal }} \times 100 \%
$$

Kriteria interprestasi skor angket sesuai dengan kategori penilaian angket di bawah ini:

\begin{tabular}{ll} 
Tabel 2. & Kategori Penilaian Angket \\
\hline Interval & Kategori \\
\hline $1-20$ & Sangat Kurang Baik \\
$21-40$ & Kurang Baik \\
$41-60$ & Cukup \\
$61-80$ & Baik \\
$81-100$ & Sangat Baik \\
\hline
\end{tabular}

\section{HASIL DAN PEMBAHASAN}

Setelah dilakukan kegiatan pelatihan hidroponik di SMP $\mathrm{N} \quad 8$ Semarang, adapun kegiatan pelatihan ini dilakukan untuk membangun sikap peduli dan minat siswa terhadap lingkungan dengan hidroponik. Dalam mengetahui hal tersebut dilakukan penelitian dengan mengukur seberapa besar sikap peduli serta minat siswa melalui pengisian angket sebelum perlakuan dan setelah perlakuan secara behavioral checklist. Terdapat 6 aspek yang menjadi penilaian pada pelatihan ini, yaitu Pemanfaatan Media pada Hidroponik, Proses Penanaman Hidroponik, Pemahaman/ Penguasaan Materi Hidroponik, Kepedulian Siswa terhadap Lingkungan, Minat Siswa pada
Pengembangan Teknologi Hidroponik, dan Pelestarian Lingkungan. Angket sebelum dan sesudah pelatihan berupa pernyataan yang disesuaikan dengan persepsi siswa dengan mengukur seberapa besar sikap peduli dan minat siswa terhadap lingkungan melalui kegiatan hidroponik. Berdasarkan hasil penilaian disajikan data berupa tabel jumlah skor sebelum dan sesudah.

Tabel 3. Hasil Peningkatan Skor Angket Masingmasing Siswa

\begin{tabular}{|c|c|c|c|}
\hline $\begin{array}{l}\text { Indikator } \\
\text { Penilaian }\end{array}$ & $\begin{array}{l}\text { Skor Se- } \\
\text { belum }\end{array}$ & $\begin{array}{l}\text { Skor Se- } \\
\text { sudah }\end{array}$ & $\begin{array}{l}\text { Pening- } \\
\text { katan }\end{array}$ \\
\hline RA01 & 92,1 & 96,2 & 4,1 \\
\hline RA02 & 88,2 & 99,3 & 11,1 \\
\hline RA03 & 86,4 & 93,7 & 7,3 \\
\hline RA04 & 69,4 & 94,3 & 24,9 \\
\hline RA05 & 89,4 & 97,5 & 8,1 \\
\hline RA06 & 92,9 & 97,5 & 4,6 \\
\hline RB01 & 72,3 & 95,6 & 23,3 \\
\hline RB02 & 75,4 & 96,8 & 21,4 \\
\hline RB03 & 62,9 & 95 & 32,1 \\
\hline RB04 & 93,5 & 99,3 & 5,8 \\
\hline RB05 & 80,6 & 73,7 & $-6,9$ \\
\hline RB06 & 81,2 & 95,62 & 14,42 \\
\hline RC01 & 78,2 & 97,5 & 19,3 \\
\hline $\mathrm{RC} 02$ & 74,7 & 95 & 20,3 \\
\hline $\mathrm{RC} 03$ & 62,3 & 89,3 & 27 \\
\hline $\mathrm{RCO} 4$ & 70,5 & 88,7 & 18,2 \\
\hline $\mathrm{RC} 05$ & 84,7 & 91,8 & 7,1 \\
\hline RC06 & 81,1 & 96,8 & 15,7 \\
\hline $\mathrm{RC} 07$ & 81,1 & 90 & 8,9 \\
\hline RD01 & 87 & 96,2 & 9,2 \\
\hline RD02 & 67,6 & 88,7 & 21,1 \\
\hline RD03 & 85,8 & 92,5 & 6,7 \\
\hline RD04 & 83,5 & 84,3 & 0,8 \\
\hline RD05 & 73,5 & 95,6 & 22,1 \\
\hline RD06 & 76,4 & 94,3 & 17,9 \\
\hline RE01 & 78,8 & 93,1 & 14,3 \\
\hline RE02 & 64,1 & 83,1 & 19 \\
\hline RE03 & 80,5 & 95,3 & 14,8 \\
\hline RE04 & 85,2 & 95,6 & 10,4 \\
\hline RE05 & 72,9 & 83,7 & 10,8 \\
\hline RE06 & 74,1 & 91,2 & 17,1 \\
\hline RE07 & 83,5 & 83,75 & 0,25 \\
\hline RF01 & 89,4 & 96,2 & 6,8 \\
\hline RF02 & 84,7 & 91,2 & 6,5 \\
\hline RF03 & 88,2 & 89,3 & 1,1 \\
\hline RF04 & 64,7 & 73,75 & 9,05 \\
\hline RF05 & 60,5 & 76,8 & 16,3 \\
\hline RF06 & 88,8 & 86,8 & -2 \\
\hline Jumlah & 3006,1 & 3475,02 & 468,92 \\
\hline Rata2 & 79,1 & 91,4 & 12,3 \\
\hline
\end{tabular}


Berdasarkan tabel di atas diketahui bahwa dari 28 Indikator Penilaian dengan 34 responden(siswa) menunjukkan bahwa rata-rata yang dihasilkan setelah melalui perhitungan skor masingmasing yaitu sebanyak 79,1 pada skor sebelum pelatihan, dan 91,4 pada skor setelah pelatihan. Yang berarti terjadi peningkatan skor angket pada masingmasing siswa.

Kemudian dari data yang sudah ditampilkan, disajikan pula berupa grafik peningkatan merupakan data rata-rata hasil dari jumlah skor sebelum dan sesudah perlakuan dari angket masingmasing siswa.

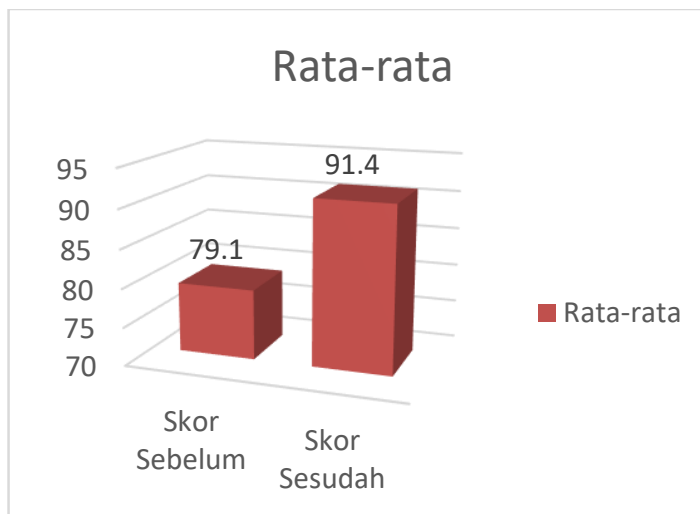

Gambar 5 Grafik Peningkatan Nilai Angket Siswa Sebelum dan Sesudah

Angket sebelum perlakuan menunjukkan bahwa nilai rata - rata angket sebesar 79,1. Artinya sebelum adanya perlakuan pelatihan hidroponik minat bercocok tanam siswa terhadap hidroponik masih tergolong dalam kategori baik, hal ini dikarenakan siswa sudah memiliki rasa senang terhadap tanaman namun belum mengerti bagaimana cara memperlakukan tanaman mulai dari penyemaiannya, pembuatan nutrisinya, perawatannya, bahkan hingga tiba masa panen.

Minat siswa akan tumbuh, ketika ada suatu perasaan senang, ketertarikan, kepedulian siswa terhadap suatu objek tertentu. Adanya perbedaan nilai angket antara sebelum perlakuan dan setelah perlakuan menunjukkan perkembangan siswa yang baik dalam menerima suatu pembelajaran. Minat bercocok tanam secara hidroponik siswa mengalami peningkatan sebesar $12,3 \%$ dari nilai sebelumnya. Peningkatan nilai angket ini dibuktikan dengan hasil rata - rata angket sebelum penelitian sebesar 79,1 dan angket setelah penelitian sebesar 91,4. Angket ini menunjukkan bahwa siswa mulai tumbuh sikap peduli lingkungan dan minat dalam bercocok tanam setelah siswa mengetahui dan melakukan penelitian hidroponik secara langsung.

\begin{tabular}{|c|c|c|}
\hline $\begin{array}{l}\text { Pengelompok- } \\
\text { kan Indikator } \\
\text { Penilaian }\end{array}$ & $\begin{array}{l}\text { Skor } \\
\text { Sebelum }\end{array}$ & $\begin{array}{l}\text { Skor } \\
\text { Sesudah }\end{array}$ \\
\hline RA01-RA06 & 86,4 & 96,41 \\
\hline RB01-RB06 & 77,65 & 92,67 \\
\hline RC01-RC07 & 76,08 & 97,72 \\
\hline RD01-RD06 & 78,96 & 91,93 \\
\hline RE01-RE07 & 77,01 & 89,39 \\
\hline RF01-RF06 & 79,38 & 85,67 \\
\hline Jumlah & 468,48 & 553,79 \\
\hline Rata-rata & 78,08 & 92,59 \\
\hline
\end{tabular}

Berdasarkan tabel di atas diketahui bahwa pada perhitungan dari ke-6 aspek penilaian terjadi peningkatan sebesar $14,51 \%$ dari nilai skor sebelum dengan rata-rata 78,08 termasuk dalam kategori penilaian baik, sedangkan pada nilai skor sesudah dengan rata-rata 92,59 termasuk dalam kategori penilaian sangat baik. Dan nilai tertinggi yaitu 97,72 yang menunjukkan aspek Pemahaman/ Penguasaan Materi Hidroponik. Data tersebut menunjukkan progres baik dari siswa karena sebelum pemberian materi dan praktik penanaman, tidak semua siswa mengetahui hidroponik dengan detail. Namun setelah diberikan materi dan dari siswa melakukan praktik langsung penanaman, siswa semakin memahami dan menguasai teknik menanam hidroponik selain lebih mengerti hidroponik, adapula rasa ingin memunculkan jiwa lingkungan yang baik 
dengan mencoba melakukan penanaman di rumah masing-masing dalam kehidupan sehari-harinya.

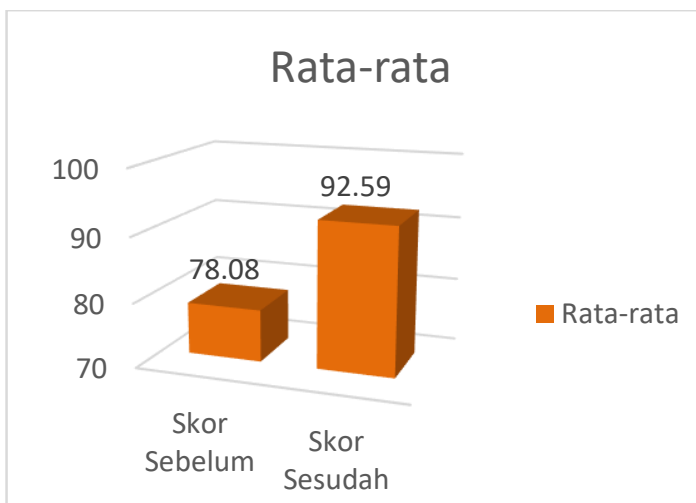

Gambar 6. Grafik Peningkatan Tiap Aspek Penilaian Sebelum dan Sesudah

Angket sebelum perlakuan menunjukkan bahwa nilai rata - rata angket sebesar 78,08. Artinya sebelum adanya perlakuan pelatihan hidroponik minat bercocok tanam siswa terhadap hidroponik masih tergolong dalam kategori baik, hal ini dikarenakan siswa sudah memiliki rasa senang terhadap tanaman namun belum mengerti bagaimana cara memperlakukan tanaman mulai dari penyemaiannya, pembuatan nutrisinya, perawatannya, bahkan hingga tiba masa panen.

Minat siswa akan tumbuh, ketika ada suatu perasaan senang, ketertarikan, kepedulian siswa terhadap suatu objek tertentu. Adanya perbedaan nilai angket antara sebelum perlakuan dan setelah perlakuan menunjukkan perkembangan siswa yang baik dalam menerima suatu pembelajaran. Minat bercocok tanam secara hidroponik siswa mengalami peningkatan sebesar $12,3 \%$ dari nilai sebelumnya. Peningkatan nilai angket ini dibuktikan dengan hasil rata - rata angket sebelum penelitian sebesar 79,1 dan angket setelah penelitian sebesar 91,4. Angket ini menunjukkan bahwa siswa mulai tumbuh sikap peduli lingkungan dan minat dalam bercocok tanam setelah siswa mengetahui dan melakukan penelitian hidroponik secara langsung.

Penelitian yang telah dilakukan mendapatkan respon dan antusias yang baik dari siswa. Sehingga pembelajaran tentang hidroponik baik diterapkan di sekolah, untuk mengajak siswa belajar bercocok tanam sejak dini. Hidroponik dalam pelajaran biologi sekedar materi singkat sebagai pengenalan ke siswa. Jarang sekali materi tentang pembuatan hidroponik dipraktikkan langsung oleh siswa, karena hidroponik bukan merupakan materi pokok dalam pelajaran. Sehingga tidak heran, jika sebagian siswa masih awam tentang hidroponik. Menindak lanjuti dari penelitian yang telah dilakukan didapatkan respon yang berbeda-beda dari setiap siswa.

Sebagian siswa tertarik untuk mulai melakukan hidroponik sebagai hobi yang akan menghantarkan ke peluang usaha, namun sebagian siswa tidak dapat mengembangkan hidroponik karena terkendala bahan-bahan untuk hidroponik, sehingga siswa enggan melakukannya. Penilaian guru terhadap pelatihan hidroponik yang diadakan oleh peneliti memberikan dampak positif bagi siswa, karena pelatihan ini dapat diaplikasikan di kehidupan sehari - hari siswa. Penelitian ini juga tidak lepas dari pengumpulan foto - foto selama penelitian berlangsung. Selain itu, dokumentasi tentang sekolahan juga dibutuhkan sebagai bukti adanya penelitian yang berlangsung di SMP Negeri 8 Semarang.

\section{SIMPULAN}

Penelitian yang telah dilakukan di SMP N 8 Semarang dapat disimpulkan bahwa sikap ramah siswa terhadap lingkungan melalui pelatihan hidroponik sangat baik khususnya dilihat dari aspek penilaian minat siswa pada Proses Penanaman Hidroponik, Pemahaman/ 
Penguasaan Materi Hidroponik dan Pengembangan Teknologi Hidroponik. Bahwasanya siswa disini sebagai pemula diharapkan mengerti terlebih dahulu perkembangan pertanian saat ini secara modern dengan hidroponik, dan untuk mendukung pembelajarannya yaitu dengan diberikan pemahaman tentang materi tersebut.

\section{UCAPAN TERIMAKASIH}

Ucapan terima kasih penulis sampaikan kepada pihak SMP N 8 Semarang yang telah memberikan izin dan dukungan untuk menjadi jembatan bagi terselenggaranya pelatihan hidroponik ini.

\section{DAFTAR PUSTAKA}

Alviani, P. 2015. Bertanam Hidroponik Untuk Pemula. Jakarta: Ibit Publisher.
Maghfiroh, L. 2017. Minat Bercocok Tanam Siswa Dengan Menggunakan Teknologi Hidroponik. Jurnal Skripsi UIN Walisongo

Daryanto\&Darmiatun. 2013. Implementasi Pendidikan Karakter di Sekolah. Yogyakarta: Gava Media.

Widoyoko, Eko Putro. 2014. Teknik Penyusunan Instrumen Penelitian. Yogyakarta: Pustaka Pelajar.

Undang-Undang Nomor 32 Tahun 2009 tentang Perlindungan dan Pengelolaan Lingkungan Hidup. Diunduh pada tanggal 28 Juli 2019 pukul 14.52 WIB

https://id.wikipedia.org/wiki/Hidroponik, diakses pada tanggal 28 Juli 2019 pukul 14.36WIB 